\title{
Insânia loquaz, ocasionada por uma pneumonia crônica, com tubérculos pulmonares? O bservação do sr. dr. Jobim, membro titular, lida na Sociedade de Medicina, na sessão de 30 de dezembro de 1830*
}

José Martins da Cruz Jobim

Silvestre, de uma constituição atlética, entrou no Hospital da Misericórdia há mais de ano, como louco. Sua loucura consistia em falar muito com voz forte e cheia e, como dava a perceber, tinha muitas alucinações, em que se lhe apresentavam diferentes pessoas com quem conversava, e estava sempre em disputa; isto com grande volubilidade, mudando a cada instante de objeto; no meio destas desordens da inteligência comia e bebia como se nada tivesse, sem se queixar de coisa alguma. Ele tinha um semblante carregado, e melancólico, e quando acontecia estar calado, se se lhe perguntava alguma coisa, então começava as suas vociferações e seus diálogos. Ele foi pouco a pouco emagrecendo; começou a lançar escarros purulentos em grande abundância, e faleceu no dia 17 de dezembro de 1830 .

* Publicado originalmente em Semanário de Saúde Pública, Rio de Janeiro, n. 36, p. 185, set./1831. Foi feita atualização ortográfica do texto. 
Necropsia: no ventre serosidade purulenta com algumas aderências em pequeno número, formadas por falsas membranas; o interior do canal intestinal são, assim como os mais órgãos do ventre; no peito aderência íntima da metade superior dos pulmões às pleuras costais; a parte superior dos pulmões hepatizada, no esquerdo havia três grandes cavernas, no direito mais duas pequenas; no meio do tecido pulmonar hepatizado havia grande número de pequenos tubérculos irregularmente circunscritos; o pericárdio dilatado continha 4 a 5 onças de serosidade; o coração estava perfeito. Os ossos do crânio eram duros e espessos; bastante serosidade entre a aracnóide; por baixo desta membrana, na parte convexa do hemisfério cerebral direito havia, o que já encontrei em outro doido, uma porção de sangue disseminado igualmente na extensão de três polegadas, a substância cerebral no estado perfeito; os ventrículos laterais tinham uma capacidade tripla da ordinária, e estavam cheios de uma serosidade límpida, reputada em seis onças; a extremidade inferior do septum tranverso rota dava comunicação entre os dois ventrículos. 